\title{
Effect of AIPAC Lobby on America's Foreign Policy towards the Islamic Republic of Iran
}

\author{
Marziehe Shakoori $^{1,2}$, Davood Kiani ${ }^{1,2} \&$ Masha Allah Heidarpour ${ }^{2}$ \\ ${ }^{1}$ Department of International Relations, Science and Research Qom Branch, Islamic Azad University, Qom, Iran \\ ${ }^{2}$ Department of International Relations, Qom Branch, Islamic Azad University, Qom, Iran \\ Correspondence: Davood Kiani, Department of International Relations, Science and Research Qom Branch, \\ Islamic Azad University, Qom, Iran. E-mail: kiani@iras.ir
}

$\begin{aligned} & \text { Received: February 14, } 2016 \quad \text { Accepted: June 17, } 2016 \quad \text { Online Published: July 31, } 2016 \\ & \text { doi:10.5539/jpl.v9n6p129 }\end{aligned} \quad$ URL: http://dx.doi.org/10.5539/jpl.v9n6p129

\begin{abstract}
Undoubtedly, no countries have been, by now, the host and under the influence of pressure groups as far America would, the issue make difficult to make a decision in foreign policy affairs, because of the benefits and the valuation system in America. It seems that among the pressure groups in America, the Israel lobby in America has the most influence on the foreign policy-making; accordingly it can be said almost there has been a special relationship between America and Israel after World War II and AIPAC always guarantees this relationship to continue. In shaping the foreign policy of any country, a collection of internally, nationally and internationally different-level factors would contribute that the outcome of the interaction between these factors has been provided as an output and called by "foreign policy". United States of America's foreign policy has been the outcome of such a process, accordingly, on the basis of theories of international relations that the internal level would be the most essential level of the analysis of the foreign policy of the United States of America, which one of its components is to examine the role of pressure groups in shaping this country's foreign policy, actually in this regard, there is no the most prominent and significant lobby group except Israel lobby in America. So, author intends to investigate the influence of various forms of Israel lobby and this regime position and performance within America's foreign policy against Iran and thereby, the lobby's directed activates in the arena of Iran were investigated; followed by the research process, stated that the penetrating element in the decision-making system of the United states of America is undeniably in terms of the Israeli-centered influential lobby groups' contribution and the unsparing support of the United states for this lobby.
\end{abstract}

Keywords: AIPAC, lobbying, foreign policy

\section{Introduction}

In shaping the foreign policy of any country, a collection of internally, nationally and internationally different-level factors would contribute that the outcome of the interaction between these factors has been provided as an output and called by "foreign policy". United States of America's foreign policy is the outcome of such a process and the interaction of these levels comes Tuesday. American's foreign policy is driven such a process and this originates from interaction between three levels. Based on the theories of international relations, the internal level would be one of the major surfaces in the foreign policy analysis of the United States of America that explores the role of parties Democratic and Republican, prominent leaders and politicians of Congress, public opinion, big business owner, think room and pressure groups involved in the formation of foreign policy. Meanwhile, when the America's foreign policy in the Middle East is under discussion, the role of the Israel's lobby, among other factors, is more prominent and more significant. Despite the above information in the study of international relations, one thing that has been preoccupied the author's mind and basically the author is trying to evaluate it is which are the factors specifically that caused Israel is relied as the place of reliance by United States of America in international communications programs? And if there is such reliance, what are the factors to empower Israeli Packs lobby in the United States interactions?

The main research question is to evaluate the effect of different forms of Israel lobby and its position and performance on US foreign policy against Iran.

Since the process of exchange and globally interaction of the United States of America especially in the Middle 
East due to the common interests with Israel would be organized based on the configuration of this regime and with regard to the review of process and layout of lobbying structures of the regime, the need to evaluate how to form and to empower the lobbying groups of Israel and the United States of America influenced by the lobbies in its foreign policy, and its effect on Iran's international presence of Iran have also been effective, this analysis review of the fluctuations and impressionability of the United States in its foreign policy towards Iran are considered as a central necessity of this research.

According to surveys, the scientific and useful researches were conducted on the influence of the Israeli lobbing on US foreign policy, but an indication studied by the research is the impressionability of the US by the Israeli lobby on foreign policy towards Iran so that in fact, investigates the United States of America's impressionability against Iran in detail. Of course, there is some literature, also short excerpts of which were related to the subject of the present study.

For example, book "Jewish lobby and America's foreign policy (with emphasis on the illustration of the Jewish lobby against Iran" by doctor A. Keyvan Hosseini studied why the lobby to advocate for Israel in America is empowered and it is seeking that by providing a framework of decision-making theory, analyzed this process (the lobby is empowered to advocate for the Israeli) and he believed "given the contexts and factors expressed, the lobby has increased its power over time cumulatively, although in this way also this is faced with challenges including: also some presidents of America (which, of course, it is a cross-sectional research) ignoring the lobby make challenges to support the Israel, within the Jewish community (albeit weak). But in general, it seems that this lobby will remain still the most important influential and impressionable group on foreign policies of the United States of America. Also book "The Israel Lobby and US foreign policy America" by two authors, Stephen M. Walt and John J. Mearsheimer, translated by R. Montazami and M. Nasr was published by Khoursandi Pub. This book, when published, was propound in the think forum, research centers and between the people of West open-mind communities and it prompted many challenges. The work was origin and initiation to writing many books and articles and discussion about that the Israel lobby network dominates America and Europe and having published this, the Israel lobby came into common discourse and political literature of the West.

As well as the research, so far conducted, on the influence of the Zionist lobbying on America's foreign policy towards the Islamic Republic of Iran, the author is the tidewaiter, in particular, pursues the lobbying influence in America's foreign policy toward Iran; and this study innovates the subject of the research that there has been no research in this regard merely by relevance with Iran; so under a documentary approach, the author interprets and describes the influences of the lobby on America's foreign policy toward Iran. This is descriptive, interpretative study and based on documentation.

This means that it is trying to investigate the role of the Israel lobby on America's foreign policy toward Iran in the descriptive and interpretative way as an independent variable and the America's moving to adopting the policy of containment of the Islamic Republic of Iran as a dependent variable.

Today the study of pressure groups is an important issue in shaping the public policy. The groups are trying variously to affect the shaping the policies and taking the decisions to maximize their own interests. Join studies related to interest groups goes back to the beginning of the 20th century, however, this phenomenon is not new thing and even though dates back over the old parties, the original concept of the pressure group also called by the influential group was drawn first in America, and this was surveyed to study the impact of agencies and private associations on the government (Douvrezheh, 1993, 535). Although it can be argued that the most political decisions are influenced by the activities of pressure group, the study of these groups is not considered to the extent to which have been involved in the political process. However, in some pluralistic societies due to the abundance and diversity of these groups in the field of sociology, no considerable research has been done about them. On the contrary, the traditional and totality systems due to the political structure within which they operate make a way limited for the formation, growth and activities of these groups. On the other hand, one of the factors that makes it difficult to study the interest groups and prevent to achieve a certain result is their programs and behavior hidden and complex, this reaches its peak particularly in underdeveloped communities (Naghibzadeh, 1988, 15 and 13), this is so important that some political theorists believe that today the political regime should be studied on the basis of parties, but role and function of the pressure groups and stakeholders should be studied (Kourdnaej, 2007, 67).

\section{America's Foreign Policy}

Historically, America's policy has always fluctuated between idealism and realism. America-centric foreign policy during the past half-century has been to establish the continued stability and international discipline. The discipline to promote and institutionalize political and economic patterns of America was essential on the global 
stage which has being still looked whether during the Cold War or after the collapse of the Soviet Union. Foreign policy of the United States of America would be included along with special features that later, the most important ones will be discussed.

The first point refers to how it is the relationship between "American's democracy" and "foreign decision-making system", in other words, what makes democratic societies foreign decisions as the complex realm and full of surprising things is presence and influence in the different world. In one world, we confront the forces and factors such as international politics, balance of power, wars and alliances and mercenary and brutal use of arrival of diplomacy in order to influence the behavior of others and in another world, witness the domestic politics, interest groups, political parties and political classes with conflicting interests and goals. The situation, in regarding America, is accompanied with another component's contribution called "consensus in times of crisis and differentiation in the course of peace". Second, the informal style of decision-making at the level of US foreign policy, in this context, the concept of "forum decision-making," has become so common and thinkable concern, based on which utilization of special bargaining ducts consisting of a limited range of consultants and consultation would be of higher priority, compared with the official bodies such as the National security Council. The third returns the cultural and value factors influencing the foreign policy of the United States. In other words, the pattern of interaction between "the heirs' environment" becoming apparent in the way of the early settlers' co-living and communicating with the America land of pristine, vast and rich is gradually associated with certain consequences in the economic, political and social, in particular, religious (Hosseini 2009, 30-27).

\section{Pressure Groups and the Foreign Policy of America}

The lobbyists or interest groups in the United States include the groups that to achieve their own goals and interests by taking advantage of this country's legal and political structure and capacity are seeking to influence the political process and orientation, whether domestic or foreign.

In recent years, with increasing parliamentary capacity of United States, the power of groups gets increased that the main area of their activity and effectiveness in Congress and the Senate. In this context, the first function of lobbying is to providing the information the lobbies provide the required information for the members of Congress or the Senate in the following ways:

1) Providing the information regarding the future of plans and bills and vision, to approve or reject them

2) The investigation into the electoral consequences of rejection or support of bills introduced and presented to representatives

3) Informing the public about the environmental, political, economic, social and cultural consequences to approve or reject the bills referred to in the orientation of representatives.

The second function of interest groups, pressure groups would be indirect influence on the decisions of regulatory, legal and administrative (Lafuraki, 2008, 20-19).

\section{The Roots of the Israeli Lobby}

The Israel lobby in the United States is known as Israel lobby the Zionist has been trying a lot to call it as America's Jewish lobby instead of Israel lobby, According to Stephen Walt and John Mearsheimer, the Israel lobby is meant as the influential groups and organizations that are challenging how to shape America's foreign policy and with understanding the national interests resulted, and this is always trying to convince legislators, politicians and members of the Cabinet to direct their opinions and suggestions in order to protect the interests of the Israeli government (Mearsheimer, 2013, 177).

The Jewish lobby in America constitutes fundamental part and majority of American Israel lobby; these are people who invest their own time and capital profoundly to rehabilitate America's foreign policy that in this way, make sure the direction of America's foreign policy in line with Israel.

\section{The Structure of the Israel Lobby}

The Israeli lobby in America is receiving appropriate interest and benefit from two modes: Formal and informal modes. We look on groups and organizations that are trying the government, as organized, to influence the Congress and the state and direct the parliamentary and governmental interactional flows of America in Israel's interest. Like Public Affairs Committee, America - Israel known as AIPAC, but these groups under official status have powers in the field of administration and law certainly that facilitate and speed up their routine activities such as the Christian right organizations, southern whites, conservatives and neo-conservatives in both America parties must be considered also as a non-Jew agents but as a lobbyist and components and facilitators for the 
Israeli; contrary to, there is an informal mode that groups do not enter directly into the arena, but occasionally information collecting and encouraging their members to participate in the elections and political issues of the day, they are trying to influence so in America's foreign policy equations, but not in the vast circle and scope like in that of AIPAC.

The habitant Jews in America take part actively in political, social and even economic events; ironically, this social spectrum in United States have the highest rate to vote among ethnic groups. These people, although 2 to 3\% United States of America's population, almost $94 \%$ of them are living in thirteen states of America's key (Lafuraki, 2008, 104).

\section{Israel Penetration Tools}

\subsection{Influence in Congress and the Senate}

A key hub in the Israeli lobby is influence in the US Congress. Because usually the Israel is privileged against the criticism in America Congress, this is the main cause that the Congress pertains to this principle that doesn't make any changes in cases where a consensus is resulted between the representatives, and even establishing the unchanging principle in regarding Israel originates from the key members of Congress who are mostly members of the pro-Israel regime.

\subsection{Influence in the White House and President}

This is of great importance the voters influence on the presidential election. So the Israel lobby like Congress election possesses a strong leverage to impose the views, after the election of the President, the key lobby organizations, in the United States, make efforts with their own lobbying strategies that the individuals and groups opposed to the Israel not to appoint for official positions in government and not to take over important jobs. For example, Jimmy Carter intended to appoint George Ball as foreign ministry of his government and knew that the Israeli critiqued the government. So the Israel lobby opposed to his appointment, accordingly, because of there being such soul, the politicians become encouraged to openly support the Israel and by contrary, and the opponents of the regime have no space to enter the political arena (Ghavidel, 2001, 227).

In fact, the lobbies and interest groups, no matter what way directly or indirectly, to influence the United States Congress also have influence on law enforcement significantly. Most of America's presidents are less dominant against the members of Congress and sometimes take decisions in opposition to the Israeli lobby in Congress, of course, ignoring some cases, such as declining the Israel's value theory or proposing to opposing and or continuing the occupation of Palestinian territories, primarily serious opposition and certain operations against the lobby expectations would be not take placed on behalf the America's presidents, In general, the presence of Jews in America election is due to the influence of the social spectrum in America's governmental-system executive branches.

\subsection{Media Control}

One of the key tasks for the Israel lobby to demonstrate the positive effects of activities by Israeli regime would be the control and domination of the media that through top media and the most popular programs, the reports and plans of the regime are prepared and then broadcast in the community to the extent that providing news and reports by any network must be oriented to explain the function of this regime positively. For example, if serious and explicit criticism is expressed in each one of Medias about this superior regime or lobby, all the media as a group covers that criticism as form as the Israel's interests are not endangered that certainly this procedure is incompatible with the configuration of democratic society (Ghavidel, 2001, 237).

\subsection{Think Tanks}

The Israel lobby is always interested in thought associations which play an important role in shaping public debate and operational policies. The Israeli lobby has groups of advisers and prominent intellectual cores with the ability to orient the public thought in accordance with the interests of Israel. This lobby other than the reliance on high-ranking government officials in United States of America which has analyze the events in the Middle East to Israel has a collective group of thinker consultants that by hiring them, reflects the opinions of Jews in society, because this elected intellectual core interacts with America media and thus lightens the minds of the people in benefit of Israel's interests and objectives.

\subsection{Monitoring the Academic Centers}

Other cases through which the Israel lobby can exert its interests are the training centers and universities in the United States, however, due to the principle of academic freedom of thought and expression in the United States, the lobby encounters with big trouble due to this tool. The universities of America have attracted the non-US 
students and professors from around the world over 30 years, as far as the academic centers play a role as international institutions; and interestingly, the criticism of the Jewish lobby and Israel have been largely discussed by the non-native students and professors of America.

\section{America's Support of Israel Lobby}

The Israel is counted as a strategic advantage for the United States of America due to positioning geo-politically within the Jewish and the Zionist community of the country, and it is evident that today, the Israel is America's largest recipient of external aid, but this trend has continued since 1976.

From 1949 to 1965, average annual aid of America to Israel was more than \$ 63 million that more than 95\% was the aids for food and economic development and the assistance program of America to Israel was increased annually more than 102 million (Azadi, 2004, 230). It is noteworthy that America's support for Israel is always justified by the fact that since Israel is pro-democracy in the region, so it sympathizes with this country, given this situation. Albeit there are other democracy-based governments around the world who need assistance from America, however, the United States has no the least interest to them.

In general perspective, one can say that in the United States there are four main sources of funding, ideological and political support to assist the Israel's dependent economy:

1) Wealthy Jewish supporters and the powerful and coherent media in terms of fundraising

2) The Government of the United States, Congress and the President

3) The media, especially the New York Times, Hollywood and the major television networks

4) The heads of trade unions and pension fund managers

\section{Israel and AIPAC's Positions Versus Iran}

It is heartening to see, if all the policies of the United States to Iran not to be produced by the Zionist thinking, the majority of decisions of America is influenced by the Zionist approach and its related organizations. Because these organizations with authority onto America would apply the perspectives not only in Iran but also in all domestic and global issues and among the Zionist organizations, AIPAC more than all due to the proximity to the centers of power in America, Headquartered in White House, is also able to use all possible opportunities to establish and conclude their views in the Congress and Senate and other decisions-making institutions in America. So America's glance toward Iran is greatly influenced by the Zionist approach, because under an implied observing America Congress resolutions against Iran it come to a conclusion that the resolution have been adopted either on the initiative of AIPAC and Israel, or at least their overwhelming support. Meanwhile, according to the Islamic Republic of Iran's major foreign policy positioning in defense of Palestine and the denial of political legitimacy settled in Tel Aviv, this has led to the conflict between Iran and Israel with America divergence and opposition with Iran. It should be analyzed the relationships between Iran and America in following Israel's role significantly.

Israel and his propponents during the years 1984 to 1988 followed a policy of neutrality but then the Israelis treated Iran as a threat against their tripartite source. First, in terms of militarily, Iran's victory was the worst threat to Israel and second, ideologically, the Islamic Revolution serves as a model of Islamic fundamentalism in Lebanon and among the Palestinian people, and third, Iran was seen as the source of exporting terrorism in landscape of Israel.

In this regard, the Zionist lobby is regarded the most effective strong important tools within the governance system in America that is active in both formal and informal lobbies. The formal lobby includes the Jewish and Zionist organizations and organized groups that apply the pressure on the decisions of the America legislature and the government directly and most notably are American-Israeli public Affairs Committee (AIPAC) and the World Jewish Congress. The informal lobby also includes the wide participation of Jews in America elections and the presence of Jews in key positions.

Iran would be a central issue in all and annual the meetings of AIPAC the most important of which is "AIPAC National Meetings" and "AIPAC policy conference" that are held annually in October and in March, respectively, since Iran is a key theme of the meetings, this is practical and important to review the contents of Iran in the meetings, the more notable matter of these meetings would adopt a threatening approach and examine the leveraging external systems related to Iran in the United States of America that argue the issues such as sanctions on Iran, accusing it of terrorist activities and undermining the nuclear program of the Islamic Republic of Iran. AIPAC hostile policies and new issues are applied immediately by policymakers of AIPAC as a tool against the Islamic Republic, undoubtedly, with a history of AIPAC in creating an atmosphere of tension against Iran under 
the issue of alleged Iranian support for terrorism between the countries it can be realized the strategic importance of this tactic of Israel and consequently this is more obvious why an issue of Iran becomes a central matter at the meeting of AIPAC.

Iran sanctions issue is also one of the most important issues of AIPAC meetings. AIPAC committee in the mid-1990s had been trying for different reasons that the idea of Iran sanctions that turned into Iran sanctions strategy within the Jewish lobby period had raised as a priority in America's foreign policy toward Iran and enacted it as a law, the idea of blocking Iranian assets has also belong to the same sanctions (Tabatabai, 2007, p. 36).

The sanctions option against Iran has always been on the agenda for the Zionists and to operate it they have spared no effort. Accordingly, in the field of sanctions from the Israel lobby, various schemes such as bilateral containment initiatives or the D'Amato Vaylsa Act etc. approved and implemented in America in order to put pressure on Iran.

It should be noted that the process whose conclusion has reached ratification and implementation of the Iran Sanctions Act by America's foreign policy initiated from the point at the agency i.e. the Jewish lobby that "idea of sanctions" against Iran was planned. The proposed idea of sanctions by the agency was the beginning point of a process that has been designed by the agency, the sanctions plan, on one side, becomes transferred from a plan merely to a strategy for action and then the strategy has been introduced according to the characteristics of the Jewish lobby agency as part of America's national interest and then adopted and implemented (Tabatabai, 2007, 38).

According to the policies of America against the Islamic Republic of Iran, many American and Israeli sources believe the AIPAC's role in the interaction of the two countries is very penetrating and so important. Since Israel announced Iran to be its biggest enemy, given America and Israel's stress on the necessity of ending Iran's nuclear activities, the Committee has made many efforts to tighten measures of the white House against Iran in previous years, too.

Effect of the role of Zionist lobby in changing positions of the White House also highlights another point which is that this group has a plenty power in directing the foreign policy of America and this has advanced it in the Zionist regime's desired direction. Certainly, the fear of being modeled a Islamic Republic of Iran and spread of the ideas of theocracy in this country are therefore the thinkable pillar for Israel and followed by, America that for both countries' national security strategy, this situation is considered as a threat, it appears despite the fact that the Israel lobby by proposing plans such as overthrowing the regime of Iran or a military attack on the country plays a fundamental and effective role in encouraging and promoting for implementing the projects mentioned in the United States, but the statesmen of America were diagnosed "Application of an attack on Iran's nuclear facilities may result in counter-productive and disastrous consequences in the region" (Mearsheimer, 2013, 446).

\section{Conclusion}

Given the central role of the Israeli lobby and its influential tool like AIPAC in America, diplomatic, security, and even economic measures of the United States in the world, especially in the Middle East, in particular Iran, would put under the leadership of the Zionist regime and since the plotted network of America's domestic policy originates from the approaches and ideas of the Zionist, this approach exterior indication doesn't distinguish the domestic contents and hegemonic-oriented policy of America will become unmanageable by a penetrating tools such as AIPAC, and indeed, the decision-taking system of the United States is saturated in terms of the contribution of interest and benefit groups or lobbyists are defender of Israel's interests and ideas of supremacy of the ethnos, and it seems profound effects of the illustration by the interest groups especially AIPAC in America related to the occasions dominated over its international relations with the world would be undeniable as a major part of distrust ongoing within the interaction between Iran and America is mainly produced by the presence and effectiveness of stressful variables such as Israel and its lobby in decision-making structures in the United States. Obviously, Israel is not the only variable disturbing the relationship between Iran and America but the most effective assumption within the parameters of America's foreign policy is the Israel and its floating lobbies in the United States that manage America's policies towards the countries of the region, especially Iran, in order to protect its interests in the Middle East; and since the Israel is the main actor and gendarmes of America's plans in the Middle East and has had overlapping interests and identity links with this country, America would layout its plans in Israel puzzle.

Accordingly, almost all announced and applied positions and actions of the United States to the Islamic Republic of Iran over the past thirty-five years would be compliance with the demands of the Zionists to the extent that 
without considering the interests of Israel, it will never be able to earn its own interests in the Middle East.

After the revolution, due to the lack of common identity and attitudes between the people, authorities of Iran and Israel, the framework was shattered and the alliance triangle between Iran and Israel and America was disappeared. The author believes that basically the lack of political consensus on definitions such as security etc. in view of Iran and Israel regime, will provide means to occur the threatening performances in face of each other, for example, when the security will be meant merely lack of a threat against Israel and that of the internal and external threats against community values and beliefs for Iran and definitely to realize the literature governing these definitions, the performance of these systems are significant.

In this study, we tried to evaluate the impact of the Israeli main lobby and leverage in the United States of America to Iran and prove it as the researcher has considered that most of America's political decisions, particularly in the area of foreign policy towards Iran, this is matched to the views and influence of pressure groups such as AIPAC on the policy-making of the United States. Based on what was said, meanwhile, the political departments of the world, no country has influenced on America as far as Israel, precisely Israelis with American and non-American instruments make all efforts and its Zionist policy applied to impact major to Iran and its governance systems as any way as possible and did not condone any hostile actions as far to overthrow the government of Iran.

It looks different variables in America's foreign policy are trying to obtain the desired output, by entering their desired inputs in the process of foreign policy of America, this is here that the conflicting trends in the strategic relations between Iran and America have become non-convergence and non-consensus ones every day more than before, especially the high impact of groups like AIPAC in an interactive cycle of America is highly conflict-making and non-productive matter.

So if seeking to achieve the strategic goals of the Islamic Revolution in national and international dimension, we need new concerns regarding Geneva Agreement and Iran's nuclear activities and consequently the negotiations made with the United States after thirty years of left interaction between the two countries, to be considered into our domestic and foreign policy decisions effectively, because ideological values and beliefs of I.R. Iran backed by the principles of foreign policy quoted by supreme leader Khamanei contribute to make the dignity, wisdom and expediency of the regime that the general policies of Iran's international relations centered on these are stable and able to execute.

\section{References}

Charles, W. (2009). America's foreign policy, patterns and trends. Translated by A. Dastmalchi, Tehran, Institute for Political and International Studies.

Dovrezheh, M. (1993). Political sociologists. Translated by A. Ghazi, Tehran, Iran, University of Tehran.

Ghavidel, M. (2002). Book review: the religious aspect of America's foreign policy against the Arab-Israeli conflict: A Study of American Christian fundamentalist movement. Quarterly of Regional Studies (Sociology Israel - America Sociology), 3(13).

Hosseini, S. A. K. (2010a). The change trend in the pattern of Jewish minority contribution in America from immigrant minority to influential lobbyist. Quarterly of Strategic Studies of the Islamic world, 11(42).

Hosseini, S. A. K. (2010b). Redefining the role of defender lobby of the Jewish and the Israeli in America society and politics. Quarterly of Political and International Strategies, (21).

Lafuraki, B. A. (2008). The lobby and lobbying in America. Tehran, Iran, Tehran International Studies Institute of Contemporary of Abrar.

Mearsheimer, J. J., \& Walt, S. M. (2005). Israel lobby, America's foreign policy. translated by: S. Koulahi Khiabani, Hassan and H. Asgarian. Quarterly of Regional Studies of the Islamic world, 6(24).

Mearsheimer, J. J., \& Walt, S. M. (2010). Israel lobby, America's foreign policy. Translated: Abdol-mohammadi. Tehran, Iran. Saghi Publishing.

Mearsheimer, J. J., \& Walt, S. M. (2013). Translated: N. Noorizadeh. Israel lobby, America's foreign policy. Tehran, Iran. Mitra Publishing.

Meyer, A. B. (2012). Israel's response to a nuclear Iran. Translator: M. Karami. Navkesh. Quarterly of Regional Studies (Israel Studies - America Sociology), 13(3).

Mohammadi, I. A. (2005). America Network decision-making network in foreign policy focused on the Middle East file. Journal of Information, (18). 
Naghibzadeh, A. (1988). Hidden pests of democracy system. political-economic information, 4(32).

Naghibzadeh, A. (2008). An Introduction to Political Sociology. Tehran, Saamt.

Naieg, A. K. (2007). Role of pressure groups in shaping public policy (4th ed.). management culture, No. 12.

Shahraki, M. J. (2008). Theoretical Foundations of America's foreign policy after September 11. Quarterly of Strategic Research Center, (11).

Tabatabaei, S. A. (2007). America's Jewish lobby- Agency of Iran's sanction. Foreign Policy Journal, 20(1).

\section{Copyrights}

Copyright for this article is retained by the author(s), with first publication rights granted to the journal.

This is an open-access article distributed under the terms and conditions of the Creative Commons Attribution license (http://creativecommons.org/licenses/by/4.0/). 